new from (DHE PENGUIN GROUP (USA)

JOHN MAYNARD KEYNES

1883-1946: Economist, Philosopher, Statesman

ROBERT SKIDELSKY / Skidelsky has revised and abridged his three-volume biography into one definitive book. "A masterpiece of biographical and historical analysis"-The New York Times Book Review.

Penguin $\quad 1,056 \mathrm{pp} . \quad 0-14-303615-7 \quad \$ 35.00$

HAPPINESS: Lessons from a New Science

RICHARD LAYARD / One of the leading voices in the new field of happiness studies states the case: what happiness is, exactly, and how to get more of it, as individuals and as a society. "Concise and engaging."-Library Journal.

The Penguin Press 272 pp. 1-59420-039-4 \$25.95

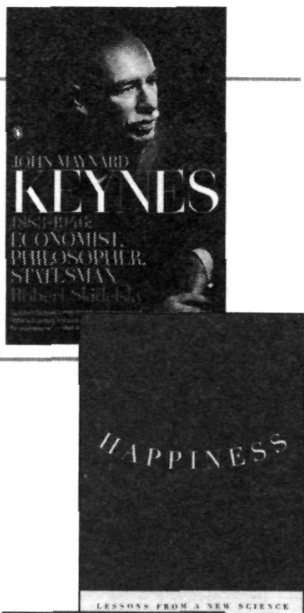

ORIGINS OF THE CRASH

The Great Bubble and Its Undoing

ROGER LOWENSTEIN / The definitive account of the dotcom boom and bust-from "one of the best financial journalists there is" (The New York Times Book Review). A BusinessWeek Top Ten Book of the Year.

Penguin $288 \mathrm{pp}$. $0-14-303467-7 \quad \$ 15.00$

\title{
BIG COTTON
}

How a Humble Fiber Created Fortunes, Wrecked Civilizations, and Put America on the Map

STEPHEN YAFA / A brilliantly researched narrative history that traces the cultural, economic, and social history of the "world's friendliest" fiber from the kingdoms of Mesopotamia to the Gap. 16-page b/w photo insert.

Viking $\quad 416 \mathrm{pp} . \quad 0-670-03367-7 \quad \$ 25.95$

\section{DEVILS ON THE DEEP BLUE SEA}

The Dreams, Schemes and Showdowns

That Built America's Cruise-Ship Empires

KRISTOFFER A. GARIN / The first ever inside look at the outrageous - and outrageously profitable-life and times of America's cruise ship industry.
Viking
$320 \mathrm{pp}$.
$0-670-03418-5$
$\$ 24.95$

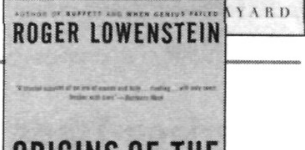

\section{ORIGINS OF THE}

0

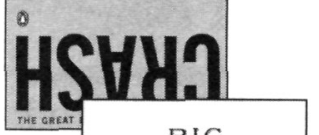

BIG

GotTon

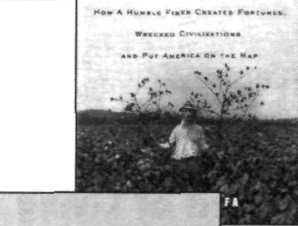




\section{Structuring the Information Age}

Life Insurance and Technology in the Twentieth Century JoAnne Yates

"A superb study. Yates provides a well-constructed and convincing study of the application of computer systems to business functioning, the people who brought about the change, and the specific gains in insurance from that application."

-Arthur Norberg, University of Minnesota Studies in Industry and Society Philip B. Scranton, Series Editor $\$ 49.95$ hardcover

\section{The Carriage Trade}

Making Horse-Drawn Vehicles in America Thomas A. Kinney

"It is an important book, of size, depth and scope well beyond what else has been written about the American nineteenth-century carriage and wagon industry." —Carolyn C. Cooper, Yale University

Studies in Industry and Society

Philip B. Scranton, Series Editor

$\$ 49.95$ hardcover

\section{Standard of Living}

The Measure of the Middle Class in Modern America

\section{Marina Moskowitz}

"Exceedingly well-written, clearly organized, and abundantly researched. There is nothing in the scholarly literature quite like this."

—Daniel Horowitz, Smith College

$\$ 45.00$ hardcover

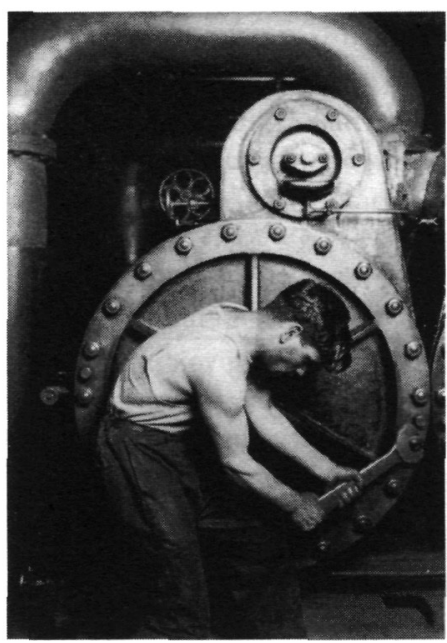

The Corporate Eye

Photography and the Rationalization of American Commercial Culture, 1884-1929 Elspeth H. Brown "Solidly grounded in the cultural, political and economic history of the Second Industrial Revolution, The Corporate Eye broadens and deepens our understanding of photography's significance to American enterprise. This work resonates critically and valuably with earlier,

heralded studies by David Nye and Roland Marchand, among others, by exploring fresh terrains and refining conceptual frameworks." -Philip Scranton

Studies in Industry and Society

Philip B. Scranton, Series Editor

$\$ 49.95$ hardcover

\section{Old Dominion, Industrial Commonwealth}

Coal, Politics, and Economy in

Antebellum America

Sean Patrick Adams

"The definitive account of how and why the coal trade developed as it did in Virginia and Pennsylvania. This is history-political, economic, and cultural history-at its finest." —John Lauritz Larson, Purdue University

Studies in Early American Economy and Society from the Library Company of Philadelphia

Cathy Matson, Series Editor

$\$ 45.00$ hardcover 


\section{New from}

\section{THE OXFORD HANDBOOK} OF WORK AND ORGANIZATION

Edited by Stephen Ackroyd, Rosemary Batt, Paul Thompson, and Pamela S. Toblert

The Oxford Handbook of Work and Organization aims to bring together, present, and discuss what is currently known about work and organizations and their connection to broader economic change in Europe and America.

$$
\begin{array}{ll}
\text { (Oxford Handbooks) } \\
\text { January 2005 } & 750 \mathrm{pp} \text {. } \\
\text { 0-19-926992-0 } & \$ 149.50
\end{array}
$$

\section{BEWARE THE WINNER'S CURSE}

Victories that Can Sink You and Your Company

\section{G. Anandalingam and Henry C. Lucas, Jr.}

In this book, Anandalingam and Lucas, Jr. expand the model of the Winner's Curse to explain how companies like Tyco, MCI-WorldCom and Bank One overpaid for acquisitions, and how shareholders suffered as a result.

$$
\begin{array}{ll}
2004 & 256 \mathrm{pp} . \\
0-19-517740-1 & \$ 29.95
\end{array}
$$

\section{REASONS AND \\ RATIONALIZATIONS}

The Limits to Organizational Knowledge

\section{Chris Argyris}

What is the purpose of social science and management research? Do scholars/researchers have a responsibility to generate insights and knowledge that are of practical (implementable) value and validity? These are some of the puzzles/pressing problems that Argyris addresses in this short book.

$\begin{array}{ll}2004 & 256 \mathrm{pp} . \\ 0-19-926807-\mathrm{X} & \mathbf{\$ 2 9 . 9 5}\end{array}$

\section{SURVIVING TRANSFORMATION}

Lessons from GM's Surprising Turnaround Vincent P. Barabba

Surviving Transformation describes how General Motors reversed a dangerous decline and repositioned itself for success in the 21st Century. 2004280 pp.; 38 halftones \& line illus. 0-19-517141-1 \$29.95

\section{LOST KNOWLEDGE}

Confronting the Threat of an Aging Workforce

\section{David W. DeLong}

This is a solution-oriented book to address one of the most pressing management problems of the coming years: How do organizations transfer the critical expertise and experience of their employees before that knowledge walks out the door?
2004
272 pp.
$0-19-517097-0$
$\$ 29.95$

\section{THE MISMANAGEMENT OF TALENT}

Employability and Jobs in the Knowledge Economy Phillip Brown, and Anthony Hesketh with Sara Williams

This book examines whether employability policies are flawed because they ignore the realities of 'positional' conflict in the competition for a livelihood, especially as the rise of mass higher education has arguably done little to increase the employability of students for tough-entry jobs.

$\begin{array}{lll}2004 & 288 \mathrm{pp} . & \\ 0-19-926953-\mathrm{X} & \begin{array}{l}\text { cloth } \\ \text { paper }\end{array} & \$ 99.50 \\ 0-19-926954-8 & \text { papr } & \$ 29.50\end{array}$

\section{THE OXFORD HANDBOOK OF INNOVATION}

Edited by Jan Fagerberg, David C. Mowery, and Richard R. Nelson

This handbook looks to provide academics and students with a comprehensive and holistic understanding of the phenomenon of innovation. An introductory overview, concluding remarks, and guide to further reading for each chapter, make this handbook a key introduction and vital reference work for researchers, academics, and advanced students of innovation.

$\begin{array}{ll}\text { (Oxford Handbooks) } & \\ 2004 & 684 \text { pp.; } 27 \text { figures } \\ 0-19-926455-4 & \$ 144.50\end{array}$

\section{ORGANIZATIONAL IDENTITY}

\section{A Reader}

\section{Edited by Mary Jo Hatch, and Majken Schultz}

This book presents the classic works on organizational identity alongside more current thinking on the issues. The readings in this volume address the key issues of organizational identity, and show how these

\begin{tabular}{|c|c|c|}
\hline 2004 & 600 pp. & \\
\hline $0-19-926947-5$ & paper & $\$ 34.50$ \\
\hline $0-19-926946-7$ & cloth & $\$ 144.50$ \\
\hline
\end{tabular}
issues have developed through contributions from such diverse fields of study as sociology, psychology, management studies and cultural studies.

Listed as one of the Economist's 2004 Books of the Year THE MODERN FIRM

Organizational Design for Performance and Growth John Roberts

The Modern Firm develops powerful conceptual frameworks for analyzing the interrelations between organizational design features, competitive strategy and the business environment. This book provides new insights into the changes going on in business today and will be of interest to academics, students and mangers alike.

(Clarendon Lectures in Management Studies)

$\begin{array}{ll}2004 & 336 \mathrm{pp} . \\ 0-19-829376-3 & \$ 27.50\end{array}$ 


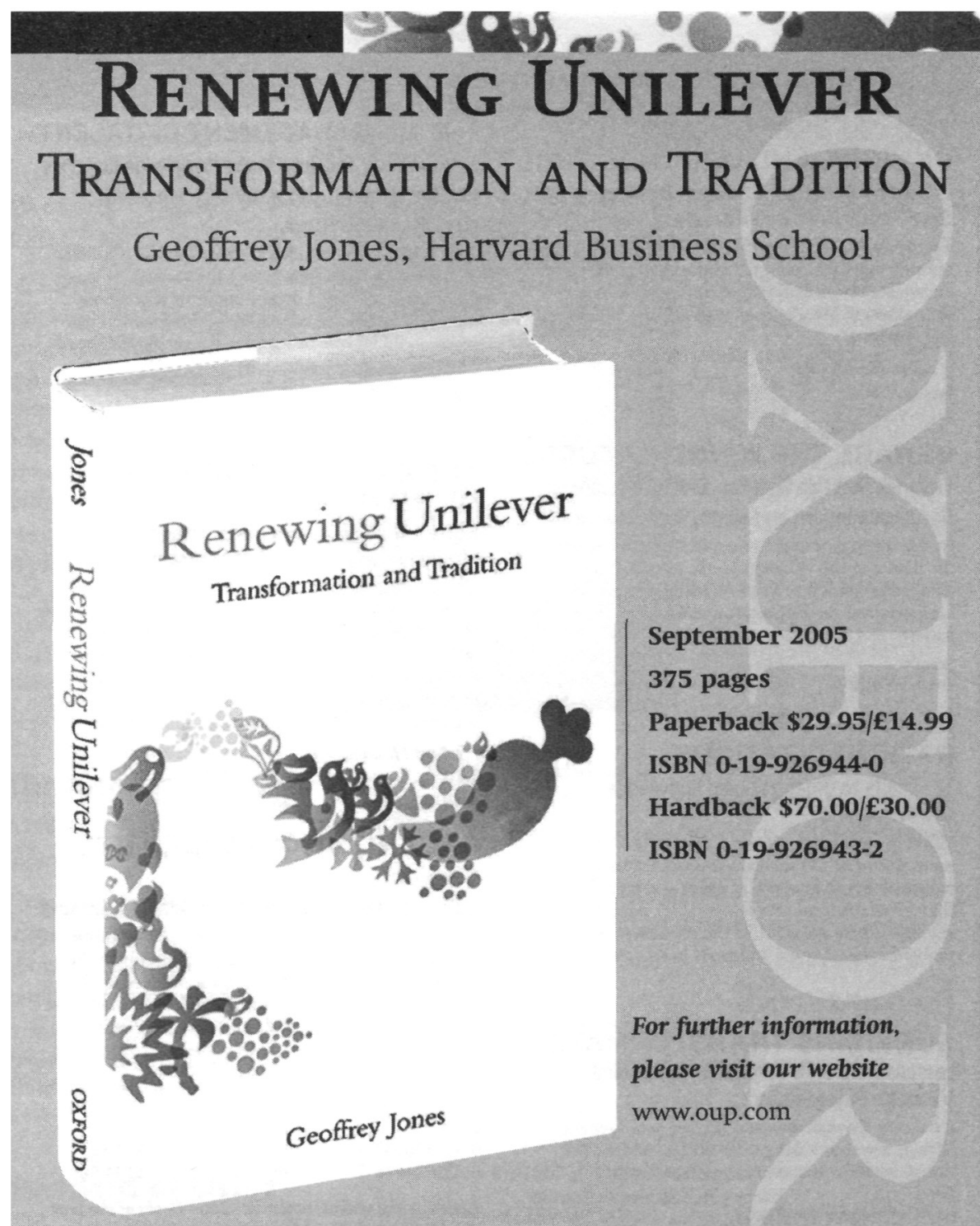

Unilever is one of the world's largest suppliers of fast moving consumer goods in foods, home and personal care. It operates in over 100 countries. Its scope and scale make it a unique global corporation. Geoffrey Jones has had full access to corporate archives and executives and provides us with a unique insight into the workings and strategies of one of the world's oldest and largest multinationals. 


\section{New Books from Texas A\&M}

\section{THE TEXAS RAILROAD COMMISSION}

Understanding Regulation in America

to the Mid-twentieth Century

\section{WILAM R. CHIIIDS}

The TRC oversaw not only railroads, but also petroleum production, natural gas utilities, and motor carriers. Before OPEC came into the picture, this agency was widely believed to set oil prices for the world. Childs's study of the TRC focuses on the interplay between business and regulators, between state and national regulatory commissions, and among the three branches of government through a process of "pragmatic federalism." $\$ 35.00$

\section{BEN LOVE}

My Life in Texas Commerce FOREWORD BY JAMES A. BAKER, III

Houston business leader Ben Love was the CEO of Texas Commerce Bancshares (TCB) in the 1980s, during the collapse of the Texas banking industry. Under his management, TCB was the only "Big Five" Texas bank to survive the economic downturn, partially because of its successful merger with the Chemical Bank of New York (now J. P. Morgan Chase). This memoir provides an inside look at the life of this exceptional banker and the evolution of banking in Texas. $\$ 30.00$

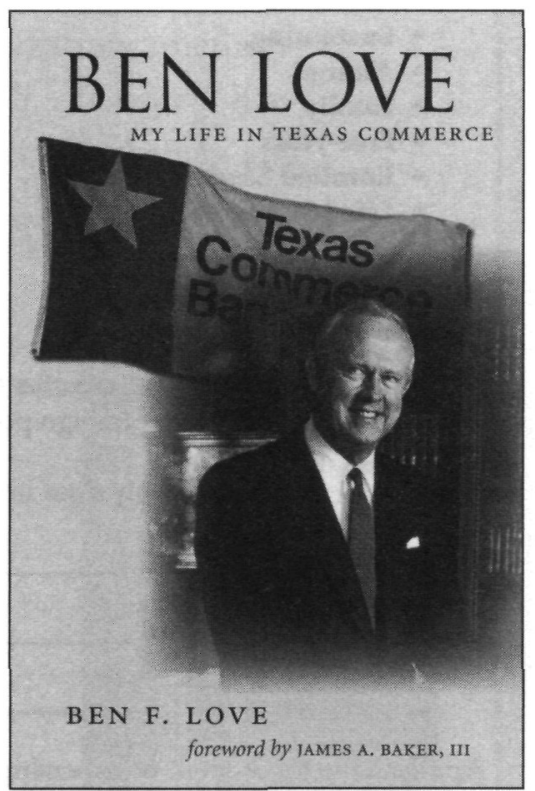

\section{TEXAS AEM UNIVERSITY PRESS}




\title{
The Journal of Southern History
}

\author{
John B. Boles, Managing Editor
}

\section{Published quarterly by the Southern Historical Association}

\section{APPLICATION FOR MEMBERSHIP}

Detach and mail with remittance to:

John C. Inscoe, Secretary-Treasurer

The Southern Historical Association

Department of History, University of Georgia

Athens, Georgia 30602-0601

\section{MEMBERSHIP CLASSES}

- Sustaining

- Annual

- Family

- Five-years

- Enrolled Student

- Life Membership

- Retired

- Library
$\$ \mathbf{4 0 . 0 0}$

$\$ 30.00$

$\$ 40.00$ (two annual meeting programs)

$\$ 125.00$

$\$ 10.00$ (send certification -6 year limit) $\$ 600.00$ (payable in quarterly payments within 1 year)

$\$ 15.00$ (member for 15 or more years) $\$ 50.00$

NOTICE: By action of the Executive Council, all memberships are on a calendar-year basis. Add $\$ 6.00$ per year for foreign postage.

I enclose \$ to pay for my dues in the Southern Historical Association.

Name

Address

Applications for student membership must be accompanied by this certificate signed by a faculty representative of the institution in which the applicant is currently enrolled.

I hereby certify that the person whose name appears on this application is currently enrolled as a student in

Signed

Position 


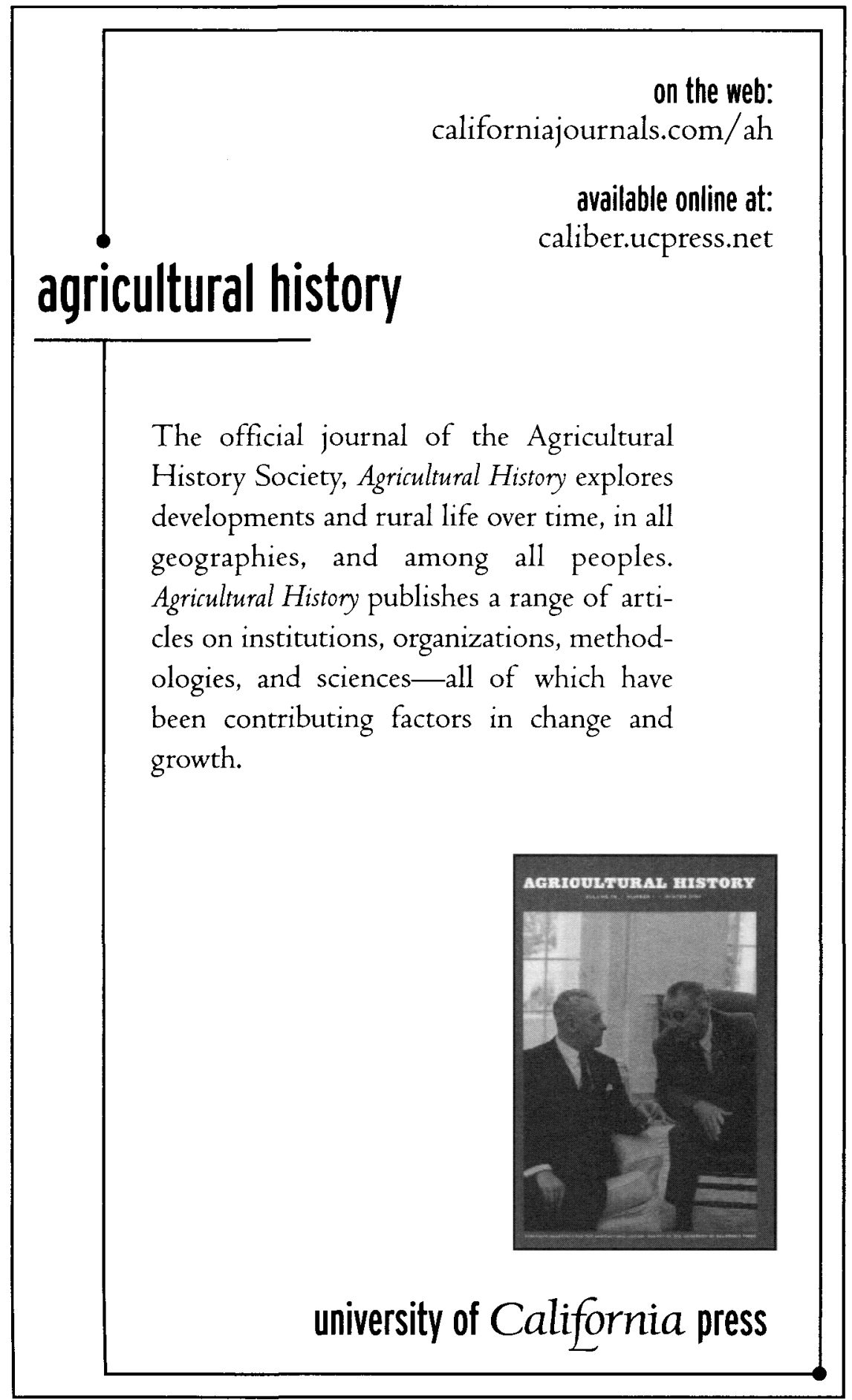




\section{GUIDELINES FOR CONTRIBUTORS}

\section{GENERAL INFORMATION}

Manuscripts are considered for publication on the understanding that they are not concurrently under consideration elsewhere and that the material-in substance as well as formhas not been previously published.

Three copies of the manuscript should be submitted.

Authors should identify themselves only on a separate title page that provides name, mailing address, and telephone number. Authors must also remember not to identify themselves in the body of the manuscript; specifically, references to their own work in the text should be in the third person, and citations should be written without possessive pronouns-not "See my ...."

Potential contributors should initially submit hard copy, not diskettes, but it will save considerable work for all parties in the event of acceptance if authors follow a few rules from the beginning:

- In general, use as few formatting commands as possible.

- Left justify text.

- Do not hyphenate words at the end of lines.

- ALL material-including extracted quotations and notes-must be double spaced.

- Notes should be numbered consecutively and citations should be placed as footnotes or endnotes formatted as indicated by The Chicago Manual of Style (1993).

- Each table and figure must be accompanied by a complete source.

Each article should be accompanied by an abstract of 75 to 100 words outlining the main point(s) of the paper and placing the article in context. Subheads should be used to divide the manuscript into three or four sections (or more, depending on length). We do not have an upper or lower page limit, but articles usually run between 25 and 50 typescript pages, including notes and other material.

We are always eager to publish illustrations, but authors should not include originals of illustrative materials at the time of submission; photocopies of such material may be included. Authors are responsible for obtaining all illustrative materials and permissions for reproduction, and for writing captions.

Authors of accepted manuscripts will receive two copies of the issue in which the article appears and twenty-five offprints.

\section{MANUSCRIPT PREPARATION}

We use the 15th edition of The Chicago Manual of Style (2003) and spell and hyphenate words according to the 11th edition of Merriam-Webster's Collegiate Dictionary.

The journal encourages authors to use gender-neutral prose in all cases where it is not anachronistic to do so; male nouns and pronouns should not be used to refer to people of both sexes. We use the day-month-year form for dates, as in 11 Feb. 1998, in the notes, but in the text, dates are written month-day-year, as in February 11, 1998. Double quotation marks should be used for direct quotation; single quotation marks are used for quoted material inside quotations.

\section{SAMPLE CITATION FORMS}

Book: Alfred D. Chandler Jr., The Visible Hand: The Managerial Revolution in American Business (Cambridge, Mass., 1977), 321-2.

Journal: Charles Cheape, "Not Politicians but Sound Businessmen: Norton Company and the Third Reich," Business History Review 62 (Autumn 1988): 444-66.

Note that we do not include the publisher in book citations. We do not use loc. cit., op. cit., or idem., but ibid. (not italicized) may be used. 
